\title{
Tintin in the Arab World and Arabic in the World of Tintin
}

\author{
Ziad Bentahar \\ Brown University
}

Hergé's adventures of Tintin have always enjoyed a considerable amount of popularity, and the recent screen adaptation by Steven Spielberg will surely increase the character's audience. Tintin's stories never ceased to draw interest not only from readers interested in the ludic world of comic books (or bandes dessinées as they are called in French), but also from a horde of enthusiasts (or tintinologists) who take the Belgian character very seriously. Intellectuals and academics have also shown interest in Hergé's oeuvre. The works of Pierre Assouline, Jean-Marie Apostolidès, Serge Tisseron and Hugo Frey are prime examples of the sort of scholarly attention that Tintin has gotten. One of the aspects of Tintin's worldwide fame is the availability of his albums in a wide array of languages and dialects-over 80 according to Tintin's official website. One of these languages is Arabic. Dar al-Maarif, an Egyptian house, distributed Arabic versions of Tintin's stories on behalf of his main Belgian publisher Casterman until 2007 when the agreement was dissolved. According to Navarro, this was seemingly due to Casterman's disapproval of Dar al-Maarif's practice of printing every other page in black and white, presumably to save on costs.

Not all of Tintin's adventures, however, were made available in Arabic by Dar al-Maarif. The absence of the first two albums is hardly surprising. The first adventure, $A u$ Pays des soviets, is rarely translated, as is the controversial Tintin au Congo. The latter has only recently been made available in English, and carries a bellyband warning readers that some may find its depiction of African people offensive. Also missing from the Arabic collection are the two albums about the lunar adventure Objectif lune and On a marché sur la lune. Most peculiarly, only one of four Tintin adventures set in the Arab World has been translated into Arabic. Why has Dar al-Maaref, Tintin's Egyptian publisher, chosen to translate Le Crabe aux pinces d'or, but not Les Cigars du pharaon, $A u$ Pays de l'or noir, and Coke en stock, all of which see Tintin travel in parts of the world-fictional and real-where Arabic is spoken? If the content of these albums is objectionable to Arabic readers, then in which ways could it be so? Moreover, what makes Le Crabe aux pinces d'or, which is set in Morocco, exceptional in that it was deemed acceptable for Arabic readers, whereas the other albums, set in Egypt and the fictional Middle-Eastern country of Khemed, were not? 
My purpose is not to make gratuitous assumptions about the political intentions of Dar al-Maarif, or reveal any sinister agenda behind (self-) censorship trends among Egyptian publishers. Rather, it is to show how the editorial choices in the Arabic translations of Tintin's stories-even when this choice is to not translate them-are revealing not only of issues pertaining to the representation of the language in Hergé's works, but also of peculiar cultural challenges in exposing one of Belgium's most recognizable characters to Islamic and Arabic-speaking audiences. Moreover, when examining the Arabic that Hergé included in the original Tintin books written in French, not only do I mean to contribute to scholarship about Hergé and his art in general, and more specifically his realist tendencies through an assessment of the accuracy of the Arabic he employed, but I also will consider the ways in which Tintin books can be experienced by bilingual readers (who know Arabic but read the books in French or English for example).

\section{Lost in Translation? Arabic in the World of Tintin}

Before Arabic, Le Crabe aux pinces d'or went through a tumultuous translation history. When it was adapted into English, the changes that had to be made to the story had an impact on the way that we know it today. As Chris Owen has pointed out, when the American publisher Golden Press decided to publish Tintin's books in the United States, they requested that a number of modifications be made to Le Crabe aux pince d'or:

"Before the translations began in earnest, Hergé agreed to redraw several panels for The Crab with the Golden Claws depicting black characters. The US censors didn't approve of mixing races in children's books, so the artist created new frames, replacing black deckhand Jumbo with another character, possibly of Puerto-Rican origin. Elsewhere, a black character shown whipping Captain Haddock was replaced by someone of North African appearance."

The changes that Hergé made to this album were kept for all subsequent editions in French. One curious outcome of these amendments is that today's English editions still have Captain Haddock asking the police to "Arrest that Negro" who whipped him (58A3), notwithstanding the character having been re-drawn. Additionally, at Golden Press's request, Hergé also had to tone down the overt description of alcohol-consumption, which plays an important role in the story.

The Arabic editors had to bring adjustments of their own to Le Crabe aux pinces d'or. Despite Hergé's concessions on the question of drinking 
alcohol, Captain Haddock's drunkenness remains crucial to the plot of this story. Dar al-Maarif, presumably concerned by the reception of alcohol consumption either by children or by Muslim readers, rendered it even more discreet by elusively calling the drinks a "beverage" "مشدروب" rather than explicitly revealing that it is whisky or rum. The other significant change made by the Arabic editors occurred in panels where Arab characters are speaking. Squiggly lines that were supposed to be Arabic and not meant to be understood by readers in the original French version were replaced by actual Arabic.
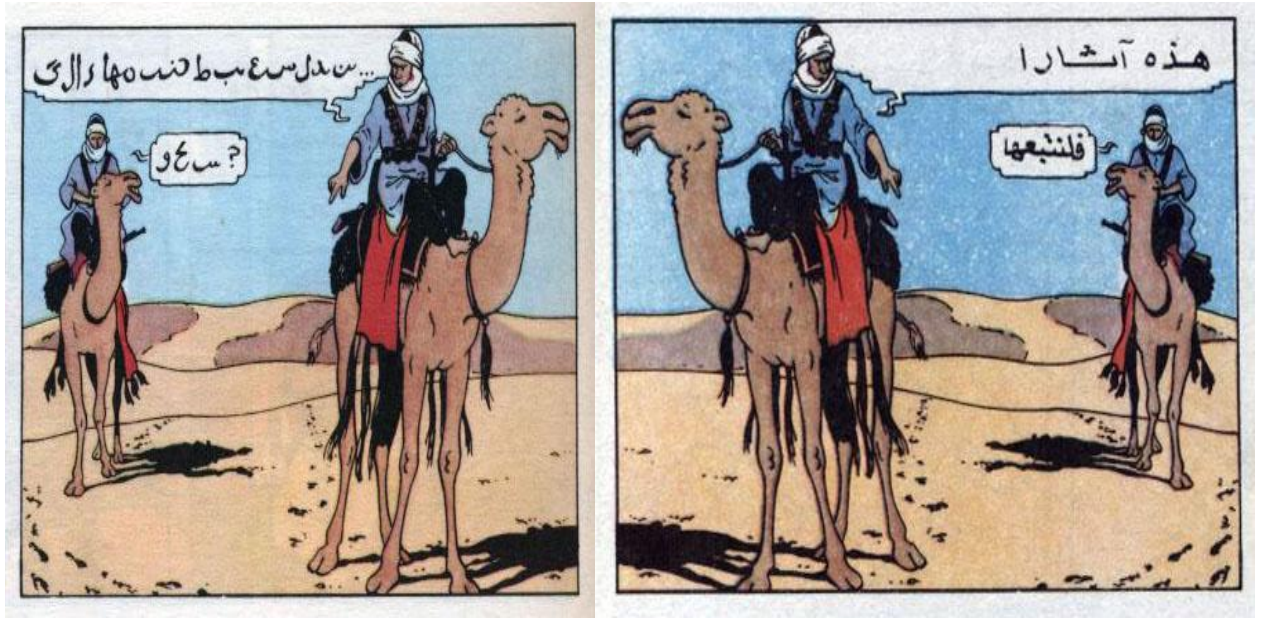

Fig.1. Vignette 32B2 of Le Crabe aux pinces d'or. To the left, the original shows the pseudo-Arabic. To the right, the Arabic version replaces the squiggly lines with actual Arabic (the characters were made to say "These are tracks/Let's follow them")

Adaptation and correction are not limited to this adventure. Hergé updated many other albums. When it comes to the stories of Tintin in the Arab World, none went through as many changes as Au Pays de l'or noir. Indeed, it has one of the most tumultuous histories in the entire Tintin canon. The story was first published in serialized form in the journal Le Petit vingtième in 1939, as were all of Tintin's stories up to that time. However, publication of Le Petit vingtieme was interrupted due to World War II, and the story was never completed. In 1948, Hergé restarted the story in Le Journal de Tintin. Six other adventures had been published in the meantime. In both of these versions, the setting is The British Mandate of Palestine. By the late sixties, the story had become anachronistic, not only due to this location, but also because of the involvement of an unnamed Jewish terrorist group modelled after the Irgun (Assouline 278). So Hergé brought more modifications, making a third and 
final version of the story in 1969. Besides changing the setting to the fictional country of Khemed and making some updates that include replacing members of the British colonial police with Arab officers, Hergé also replaced the squiggly lines that were meant to be Arabic with actual Arabic script.
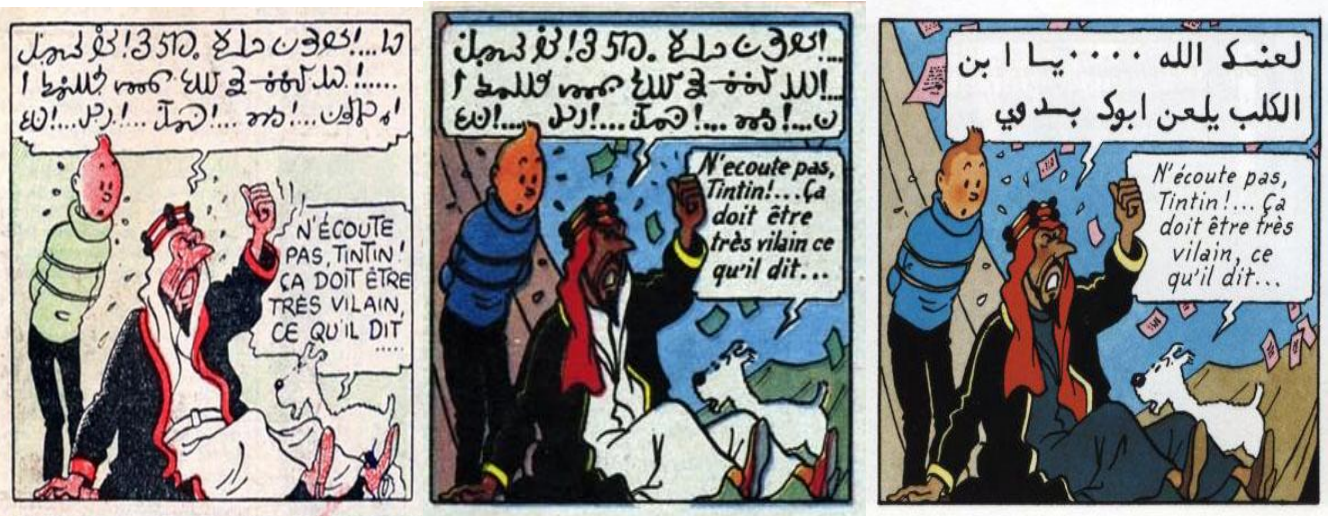

Fig.2. the same scene in three versions of Au Pays de l'or noir. Left to right, the 1939 version from Le Petit vingtième, the 1948 version, and the current version as it has been since 1969. Of all these, only the latter shows actual Arabic. The character of Bab el Ehr is saying "Goddamn you.... son of a dog damn your father Bedouin."

Hergé's attention to accuracy when it came to representing the local language is well-documented in the case of Chinese in Le Lotus bleu. As Jacques Langlois points out, Hergé's friendship with the Chinese student Tchang Tchong-jen (after whom he modeled a namesake character) was important, if only in that it led to the use of meaningful Chinese in banners, posters and street signs when he was drawing Shanghai. In that case, the signs contained slogans against Japanese imperialism. In the case of $A u$ Pays de l'or noir, the latest version does indicate a desire to be accurate with Arabic. However, in the case of Coke en stock, the subsequent story also set in Khemed, only some of the Arabic is correct. Nevertheless, in cases where it is not, it is at least clearly modeled after authentic Arabic script, and one is usually able to guess the intended meaning. 


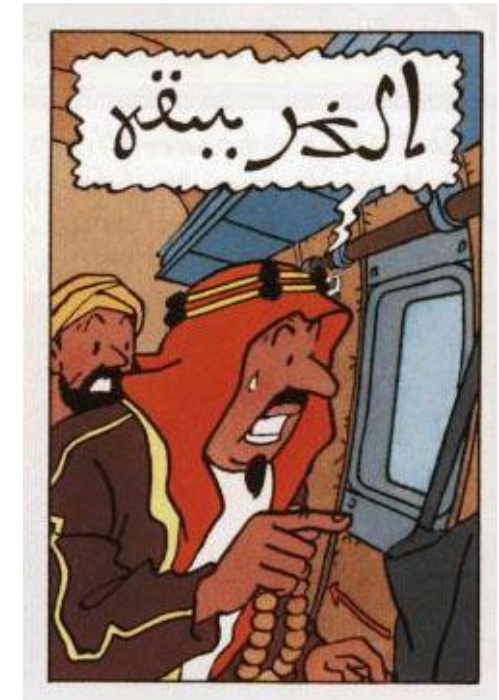

Fig.3. Vignette 17C3 of Coke en stock.

In the panel in figure 3, for instance, the reader who knows Arabic is easily able to see that the intended word is حريق [Fire!], and it is consistent with the plot (the character has just spotted a flame). However, the letters are traced incorrectly. For example, the letter $\tau$ does not connect to the letters that precede and follow it as it should, and includes a dot transforming it into a $\dot{\tau}$; also, the letter in this position should be written in its initial form $\leadsto$ rather than the medial form used here. This makes the Arabic in Coke en stock, despite its being the latest adventure set in the Arab World, halfway between $A u$ Pays de l'or noir where the Arabic is very accurate and Le Crabe aux pinces d'or where nonsensical squiggles stand in for Arabic.

Other panels containing Arabic in Coke en stock are similar to the one described above in that the script is incorrect, but not to the extent that one is unable to guess what was intended. In some of these panels, Arabic is part of the landscape. Examples of this include a street sign indicating the direction of an airport, and a poster offering a reward for the capture of the protagonists. In both of those instances, French is present and allows the reader to follow the plot. In another instance, in several vignettes the word "airbus" is written in Arabic script on an airplane; however, in this case the word only appears in Arabic. In addition to this sort of presence of Arabic as part of the background, various characters also speak it without a translation being provided to the reader, for example when two customs officers deny Tintin and the captain entry into the country at the Wadesdah airport. In such instances, the main characters themselves are not meant to know Arabic, so 
understanding the language is not crucial to the reader. In fact, not understanding it serves further identification with the protagonists as outsiders in a foreign environment, and enhances the sense of exoticism associated with the location. When the reader knows Arabic, however, being able to tell that it is incorrect, or trying to decipher the intended meaning, can distract from the flow of the story.

One striking scene that distracts the reader in this way is when Tintin and Haddock are dressed as Arab women, fully veiled to escape capture by the corrupt police who are looking for them. In this scene, a local Arab woman greets them in Arabic, assuming they will understand her. When they do not answer her, she assumes she is being scorned. So, offended, she rips off Haddock's veil in anger, and runs away in alarm when she realizes he is a man in disguise. Not only is it not necessary to know Arabic to follow the scene, not knowing it, in fact, adds to its humour as it makes it easier to sympathize with the captain when he loses his temper, frustrated that he does not understand the language. Ironically, those who know Arabic are still able to experience this scene, as are those who do not. Indeed, the script Arabic here is, much like the panel described above in figure 3, clearly inspired by real Arabic but awkward and flawed. While one who knows the language could see what the intended lines were (the phrase صباح الخير [good morning], with which the woman greets the two characters, is well written), it requires a conscious decryption effort that, if omitted, preserves the impression that the woman speaks in a foreign language. Thus, in this case, the fact that the Arabic is imperfect allows the bilingual reader who also knows Arabic to identify with Haddock and view the other character as someone who does not speak their language, just like a non-bilingual reader would.

When the Canadian entertainment company Nelvana, in partnership with the French channel Canal +, adapted Tintin's adventures into an animated series in the nineteen nineties, they had the woman in the aforementioned scene speak genuine Arabic. However, other scenes where Arabic is prominently featured are simply elided in this adaptation, such as the one where a woman admonishes Haddock after she accidentally drenches him by throwing water out the window in a Petra-inspired city. In one instance, in Les Cigars du pharaon, a character speaks nonsensical pseudo-Arabic. In various other versions of Tintin's adventures in other mediums, Arabic is also generally omitted, or replaced with gibberish. The Belvision animated series from the nineteen sixties, notorious for deviating considerably from the stories, includes the Crabe aux pinces d'or adventure. In this version, there is no Arabic, with the exception of a street sign and a store sign that show squiggles that may have been intended to be Arabic script. Another noteworthy 
adaptation of this particular story is the stop-motion film version made by Claude Misonne in 1947, marking the first apparition of Tintin on film. In this adaptation, that is faithful to the original book version, onomatopoeic clicks and nonsensical sounds stand in for Arabic when characters speak it.

\section{Portrayal of Islam: an Obstacle to an Arabic Version of Tintin au pays de l'or noir?}

One crucial difference between Le Crabe aux pinces d'or and Coke en stock, is that no one in the former speaks in Arabic to the protagonists, whereas in the latter many characters address the heroes in that language. For this reason, miscommunication and misunderstandings are part of the story of Coke en stock. However, this would not constitute an insurmountable issue for an Arabic translation, as the fact that the main characters do not understand what they are being told when they are spoken to in Arabic is not crucial to the plot. Even in the case of the woman being upset that Haddock does not return her greeting when he and Tintin are disguised as women, it could easily be assumed, in an all-Arabic edition, that the captain simply did not want to answer her for fear that his voice would give him away.

An Arabic edition of Coke en stock would be able to replace the less than perfect Arabic script used in the original. However, editing the drawings themselves would not be possible. Therefore, the most challenging obstacle would be to address misrepresentations of Islam. More specifically, prayer scenes in $A u$ Pays de l'or noir are particularly problematic. In two scenes of this story, Muslims are shown praying. In the first one, the two detectives Dupond and Dupont come upon a group of men praying as they drive through the desert, and, assuming they are a mirage, Dupont proceeds to kick one of them in the buttocks as he prostrates himself (fig. 4). 


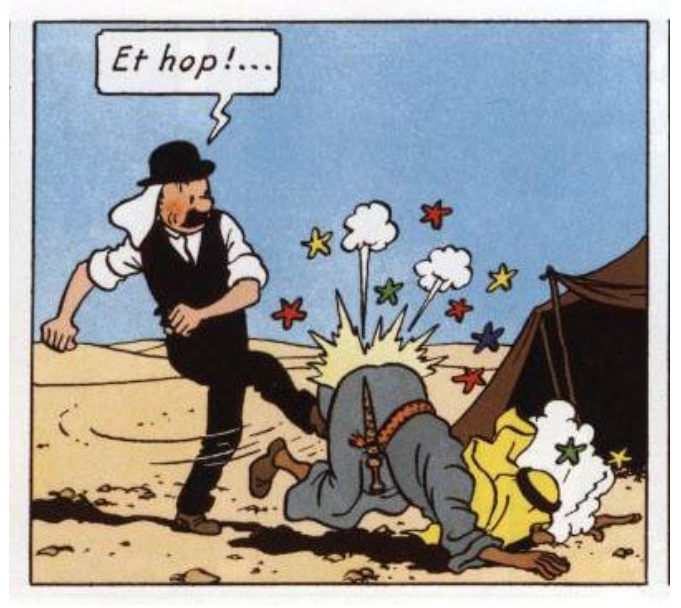

Fig.4. Vignette 22C2 of Au Pays de l'or noir.

In the second scene, the two detectives, asleep at the wheel, drive through the wall of a mosque thereby disrupting prayer. The first of these two scenes was added to the story only in its latest version, and was absent from the Petit Vingtieme and first coloured edition of 1948. It was also omitted from the animated series. The second scene, where the two detectives drive through the wall of a mosque, was part of all three versions of the story.

While the scene where Dupont kicks the man in prayer may seem particularly offensive at first, it is not necessarily so in view of the fact that the two characters' naïve disregard of customs and their inadvertently insulting behaviour is a recurrent joke in the series, and does not single out Muslims or Arabs. The issue with this, as well as the other scene where prayer is portrayed in Au Pays de l'or Noir, is the inaccuracies in the representation of Muslim prayer. In figure 4 above, the man was shown praying while wearing his shoes, when any Muslim would in fact pray barefooted. Moreover, the gestures that the men are shown to be making in both scenes, with their hands thrown towards the sky, never happen in Muslim prayer. This may remain an important obstacle for Arabic editions of the book.

Most peculiarly, however, the men praying in the mosque before Dupond and Dupont drive through the wall were drawn correctly in the very first, incomplete version of $A u$ Pays de l'or noir from Le Petit Vingtieme, but were altered in subsequent editions to show the incorrect gesture of men throwing their hands up. 

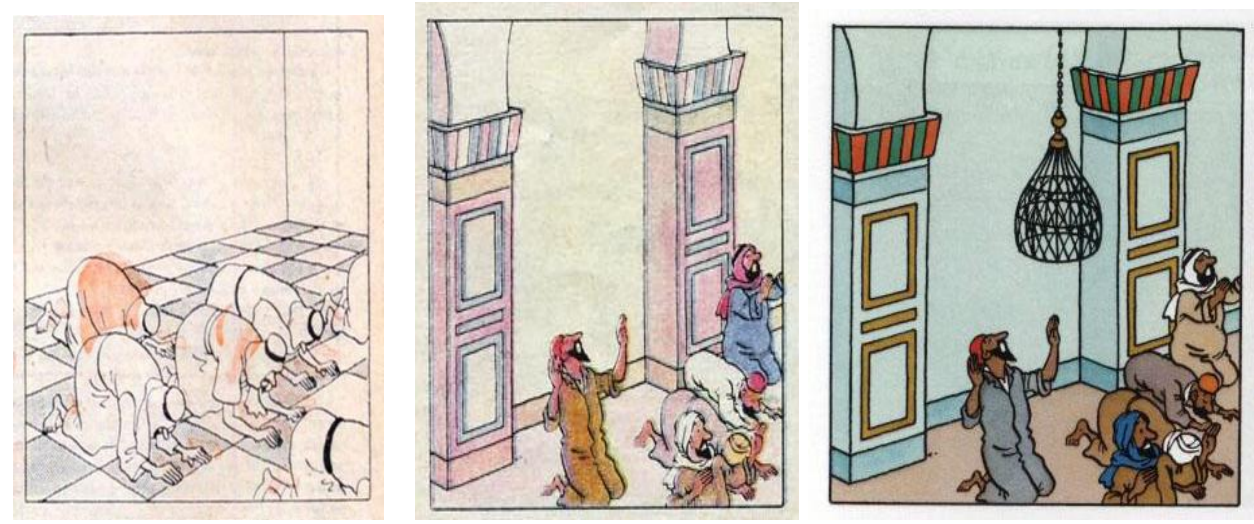

Fig.5. The same scene in three versions of Au Pays de l'or noir. Left to right, the1939 version, the 1948 version, and the current version as it has been since 1969. Of all these, only the 1939 shows correct gestures of Islamic prayer.

For this reason, the possibility of an uncensored Arabic edition of $A u$ Pays de l'or noir is extremely unlikely. Even if we do without ideological considerations, and look at the question from a purely economic perspective, non-Muslim Arabic-speaking markets remain relatively narrow, and do not justify translating the story and releasing it as is.

\section{Arab Villains}

While the matter of the portrayal of Muslim prayers in Au Pays de l'or noir is serious enough to stand in a way of an uncensored Arabic edition of the story, there is no similarly problematic issue in Coke en stock. What these two adventures have in common that might perhaps be objectionable is an unflattering portrayal of Arabs. While the foremost Arab character, the Emir Ben Kalish Ezab, is certainly not the villain of these stories, he is nevertheless depicted as an irresponsible ruler who bases important decisions on futilities. In Coke en Stock, he refuses to sign a contract with an airline company not because he objects to their involvement in a slave trafficking ring, but because they would not indulge his spoiled son's wish to see the planes perform a loopde-loop as they land.

In the adaptation of this story in the nineteen nineties' animated series, his reasons for refusing to sign the contract are changed to him opposing the kidnapping and enslavement of sub-Saharan Africans on their way to Mecca, and some of his own servants are changed from Africans to Arabs. More importantly, the particularly despicable character of the Arab slave-driver is 
omitted from this version. This suggests that concern about racially-offensive portrayals is a concern for Moulinsart, the company in charge of the commercial management of Hergés oeuvre.

If the portrayal of Arabs in Coke en stock could be seen by Arab readers as insulting coming from a European author, then why would there be no objection to portraying Omar Ben Salaad as a villain in Le Crabe aux pinces d'or? His involvement in drug trafficking is not as abject as the participation of Arabs in a Slave trafficking ring in Coke en stock, but one possible explanation as to why Omar Ben Salaad is not an objectionable villain from an Arab perspective has more to do with the cultural politics of the Arab World, and specifically that it was a Moroccan character and an Egyptian editor.

Egypt occupies a singular position in the Arabic imaginary, as a center of culture and civilization, home to such important institutions as the prestigious Al-Azhar University, and cradle of Modern Arabic literature, claiming various important authors and literary figureheads such as Naguib Mahfouz. Contrasting with Egypt, the Maghreb has been somewhat marginalized, often thought of as "not really Arab." This is partly in view of the fact that the many francophone authors to have emerged from North Africa in the aftermath of French colonialism have linked the region to a francophone intellectual scene at the detriment of ties with Arabic literary spheres. Moreover, the Maghreb's lesser place in Arabic literary canons was also validated from an ethnic perspective, considering the important Amazigh (Berber) populations in the area. Consequently, the portrayal of a Moroccan character as a villain, if taken as offensive, is not necessarily perceived to be offensive towards all Arabs, but rather towards North Africa and not the Middle East proper where Egypt sees itself.

The fourth adventure to be set in the Arab World, Les Cigares $d u$ pharaon, has Tintin travel through Egypt on his way to India. The reasons why this particular story was not translated may have nothing to do with Arabic, but rather with it being an earlier work that some may find more immature than the later adventures (for example, at one point in Les Cigares du Pharaon, Tintin plays a flute to communicate with an elephant). Nevertheless, although squiggles are used in lieu of Arabic in a few instances (similarly to Le Crabe aux pinces d'or), it does not contain any cultural or religious inaccuracies like $A u$ Pays de l'or noir (although it mentions a fictional pharaoh), nor does it portray any Arabs as villains. It is possible that the Egyptian editor chose to avoid publishing this story set in Egypt on principle, to be safe and not risk repercussion from the regime. In any case, speculating on the cause of omission of this story by Dar al-Maarif is not as revealing of cultural dynamics 
within the Arab World as is the inclusion of Le Crabe aux pinces d'or; and unlike the case of $A u$ Pays de l'or noir, there is no major obstacle standing in the way of a future Arabic version of Les Cigars $d u$ Pharaon as is.

\section{Conclusion: Which Possible Future(s) for Tintin in the Arab World in Arabic?}

Regardless of any speculative explanations for Dar al-Maarif's editorial choices in the Arabic translations of Tintin's stories, their translation of Le Crabe aux pinces d'or offers an interesting model for the treatment of Arabic in Hergés work. Possible future Arabic translations of the other adventures of Tintin in the Arab world could be done following the same approach, Coke en Stock would require more editorial work (if only because it originally contains more Arabic to be edited), whereas the representation of Islamic prayer in the drawings themselves will always be an important complication standing in the way of an uncensored Arabic version of $A u$ Pays de l'or noir.

One aspect of Tintin's adventures in the Arab World that would inevitably have to be sacrificed in an Arabic edition would be the sense of disorientation that Arabic in the original version causes the characters (and consequently the reader identifying with them) to feel. While bilingual readers who know Arabic but read Tintin in another language are able to retain this impression of disorientation when Hergé's Arabic is inaccurate, an all-Arabic version would not be able to replicate this experience. One possible solution would be to resort to attributing different dialects of Arabic to different characters. While this is improbable, if only because markets for Arabic books in any given dialect are limited, the dialects chosen for the villains and friendly characters in the stories would likely reflect the dynamics between North Africa and the Middle East.

Although discussing future Arabic editions of Tintin is only speculative at this point, the release of a film adaptation of Tintin's adventures by Steven Spielberg (which incidentally includes elements form the Le Crabe aux pince d'or, and accurate Moroccan Arabic), may cause a renewed interest in new Arabic versions of the books. The Tintin in the Congo precedent, with the bellyband warning English readers of possibly offensive content, does seem like a plausible solution if an Arabic edition of $A u$ Pays de l'or noir were to be made. However, it is also possible that this method be deemed insufficient in view of the ways in which recent portrayals of Islam and the Arab World in European cartoons have been controversial, sometimes with violent repercussions. Most notoriously, the publication of caricatures of the Prophet Muhammad in the Danish newspaper Jyllands-Posten in late 2005 caused considerable stir in news 
media across the world, and led, among other things, to the bombing of the Danish embassy in Pakistan (Walsh). More recently, the French magazine Charlie bebdo was the target of various attacks, including an arson attack against its offices and the hacking of its website, after it published various cartoons satirizing Islam and claiming the prophet Muhammad as a guest-editor to one of its issues (Samuel).

In any case, debates on racism in the Tintin stories go back at least as far as the publication of Tintin an Congo in 1931, a story tied to a colonial background. Most recently, Bienvenu Mbutu Mondondo, a Congolese student, accused the album of harbouring a racist agenda and attempted to have it banned in Belgium (Deighton). Some have deplored its portrayal of nonEuropean characters (Hunt), while others see in it simply a reflection of the times in which the stories first appeared (Mabanckou). Hergé himself remained ambiguous, and never validated either side of the debate. Nevertheless, he did sometimes revise his stories to make them less controversial. This was the case for Coke en stock, in which he altered some dialogues, namely some of the subSaharan Africans' lines, to make them seem less racially-clichéd (Peeters 107). Generally speaking, Hergé was not averse to revisions, as shown by the case of L'ile Noire, which he entirely remade to portray Great Britain more accurately at the request of his British publisher (Peeters 56). If he did revise his Arabic in Au Pays de l'or Noir, but never revised his portrayal of Arabs and Muslims beyond that, it is perhaps because none cared enough to ask, or perhaps because the European climate was never ready for such a query to occur. While Hergé is no longer here to make any revisions, the main question, when it comes to the adventures of Tintin in the Arab World, is are Europe and the Arab World ready and/or willing to discuss them? 


\section{Bibliography}

Apostolidès, Jean-Marie. Les Métamorphoses de Tintin. Paris: Seghers, 1984.

Assouline, Pierre. Hergé. Paris: Gallimard, 1996.

Coke en stock. By Hergé. Nelvana, 1992. Film.

Deighton, Ben. "Belgian Court's Adviser says Tintin Book not Racist." Reuters Africa. 31 Oct. 2011. Web. 6 Nov. 2011.

Frey, Hugo. "Céline, Hergé et l'Affaire Haddock: The Consequences of a Literary Scandal.” Etudes Francophones 20.1 (Spring 2005): 59-72.

Langlois, Jacques. "Tchang l'ami chinois." Les Personnages de Tintin dans l'Histoire. Spec. Issue of Le Point Historia July 2011: 48-50.

Hergé. “Au Pays de l'or noir." Le Petit vingtième. 1939.

--. Le Crabe aux pinces d'or. Tournai: Casterman, 1941.

---. Au Pays de l'or noir. Tournai: Casterman, 1948.

---. Coke en stock. Tournai: Casterman, 1958.

---. Au Pays de l'or noir. $2^{\text {nd }}$ ed. Tournai: Casterman, 1969.

---. The Crab with the Golden Claws. Trans. of Le Crabe aux pinces d'or. Boston: Little Brown, 1974.

---. Tintin in the Congo. Trans. of Tintin au Congo. London: Egmont, 2005.

---. al-Makbalib al-dahabiya. Trans. of Le Crabe aux pinces d'or. Cairo: Dar alma'arif, n.d.

Hunt, Nancy Rose. "Tintin and the Interruptions of Congolese Comics." Images and Empires: Visuality in Colonial and Postcolonial Africa. Ed. Paul S. Landau. Berkeley: U of California Press, 2002. 90-123.

Les Cigars du Pharaon. By Hergé. Nelvana, 1992. Film.

Le Crabe aux pinces d'or. By Hergé. Belvision, 1961. Film.

Mabanckou, Alain. “'Tintin au Congo:' Le Procès continue.” Black Bazar. 6 May 2010. Web. 6 Nov. 2011.

Misonne, Claude. Le Crabe aux pinces d'or. By Hergé. Wilfried Bouchery et Cie, 1947. Film.

Navarro, Alain. "Tintin Present in Arab World Despite Censorship.” Middle East Online. 17 Dec. 2007. Web. 11 May 2011.

Owen, Chris. "Tintin Crosses the Atlantic: The Golden press Affair." Tintinologist.org. Jan. 2007. Web. 11 May 2011.

Peeters, Benoit. Tintin and the World of Hergé: An Illustrated History. Boston: Little brown, 1988.

Samuel, Henry. "French Satirical newspaper Firebombed after Mohammed Announcement." The Telegraph. 8 Nov. 2011. Web. 8 Nov. 2011.

Tisseron, Serge. "Family Secrets and Social Memory in 'Les Aventures de Tintin." Yale French Studies 102 (2002): 145-59. JSTOR. Web. 8 Nov. 2011. 
Walsh, Declan. "Bomb at Danish Embassy Kills Six in Pakistan." The Guardian. 2 Jun. 2008. Web. 6 Nov. 2011. 